\title{
Immunohistochemical Characteristics of Estrogen Receptor $\alpha$ Positive Cells in Glandular Epithelium of the Rat Seminal Vesicle
}

\author{
Hisako Yuasa, Yoshitatsu Fukabori, Yoshihiro Ono, \\ Nao Tomita, Keiju Suzuki ${ }^{1}$ and Hidetoshi Yamanaka \\ Department of Urology, Gunma University School of \\ Medicine, Maebashi 371-8511 and ${ }^{1}$ Department of \\ Laboratory Sciences, Gunma University School of Health \\ Sciences, Maebashi 371-8514
}

Yuasa, H., Fukabori, Y., Ono, Y., Tomita, N., Suzuki, K. and Yamanaka, H. Immunohistochemical Characteristics of Estrogen Receptora Positive Cells in Glandular Epithelium of the Rat Seminal Vesicle. Tohoku J. Exp. Med., 1999, 187 (1), 25-35 — Epithelial cells of the rat seminal vesicle stained positively for nuclear estrogen receptor $\alpha(\operatorname{ER} \alpha)$. We studied these cells using immunohistochemical means. We demonstrated in a previous study that some glandular epithelial cells of the seminal vesicles of immature castrated rats treated with estrogen for 1-2 weeks had multilayer features. The present study shows that these glandular epithelial cells are nuclear ER and basal cell-specific cytokeratin $(34 \beta \mathrm{E} 12)$ positive. These findings suggested characteristics of basal cells. Moreover, we demonstrated that these cells express transforming growth factor $\beta 1$ $(\mathrm{TGF} \beta \mathrm{l})$ as a result of castration and estrogen treatment. Our findings indicate that glandular epithelial cells with multilayer features, which stained positively for nuclear $\operatorname{ER} \alpha$ have basal cell features and may play an important role in the expression of $\mathrm{TGF} \beta 1$ through an epithelial-stromal interaction. - _ - basal cell; seminal vesicle; estrogen receptor $\alpha$; cytokeratin; TGF $\beta$ (C) 1999 Tohoku University Medical Press

The seminal vesicle consists of the glandular epithelium with external secretory functions, and its surrounding stroma. It is generally accepted that the epithelium is sustained by androgen and that the stroma is a potential target for both androgen and estrogen (Mariotti et al. 1981; Thornton et al. 1984; Neubauer et al. 1989). Recent studies indicate that even small doses of estrogen can profoundly affect the growth and differentiation of the male reproductive system (vom Saal et al. 1997). To date, we have administered small doses of estrogen to immature castrated rats to determine how this hormone affects the glandular

Received June 19, 1998; revision accepted for publication January 6, 1999.

Address for reprints: Prof. Hidetoshi Yamanaka, Department of Urology, Gunma University School of Medicine, Maebashi 371-8511, Japan. 
epithelium and stroma of the seminal vesicle (Yuasa et al. 1993, 1996, 1997, 1998; Ono et al. 1995a, b). In that series of studies, we investigated localization of the estrogen receptor $(\mathrm{ER})$ using immunohistochemical methods with monoclonal antibody. Cells that stained positively for nuclear ER were densely distributed throughout the periglandular stroma region of castrated rats when compared with intact rats. In addition, the nuclear ER positive cells induced by estrogen were limited to the glandular epithelium and the peripheral stroma region (Yuasa et al. 1997). Estrogen receptors have been classified into $\alpha$ and $\beta$ subtypes, of which we have been studying the former (Kuiper et al. 1996; Mosselman et al. 1996; Byers et al. 1997; Gustafsson 1997). The present study focuses upon nuclear $\mathrm{ER} \alpha$ positive cells in the glandular epithelium, and examines some of their characteristics by immunohistochemical means.

\section{Materials and Methods}

\section{Animals and experimental protocol}

Male Wistar rats, housed under conditions of controlled temperature $\left(22 \pm 3^{\circ}\right.$ C) and lighting (lights on from $7: 00$ a.m. to 7:00 p.m.). $\beta$-Estradiol 3-benzoate $(\mathrm{E} 2-17 \beta)$ were obtained from Sigma Chemical Co. (St. Louis, MO, USA). Immature rats were castrated at 3 weeks of age, and then 3 weeks later (at 6 weeks of age) silastic tubing (cat. No. 601-335, $3.3 \mathrm{~mm}$ I.D. $\times 4.7 \mathrm{~mm}$ O.D., Dow Corning, Midland, MI, USA) containing E2-17 $\beta$ was subcutaneously implanted (Yuasa et al. 1998). The rats were killed under ether anesthesia at $0,1,2,3,7$ and 14 days thereafter. Seminal vesicles were removed and weighed. One part was fixed in $20 \%$ formalin/phosphate buffer for estrogen receptor and cytokeratin staining, and the other was frozen for TGF $\beta 1$ staining.

\section{Immunohistochemistry}

$E R \alpha$ staining. The seminal vesicle was removed and immediately fixed in $20 \%$ formalin/phosphate buffer ( $\mathrm{pH} \mathrm{7.4)}$ ) for 6 hours, and then paraffin embedded. Sections were deparaffinized, immersed in $0.01 \mathrm{M}$ citrate buffer $(\mathrm{pH} 6.0)$ and autoclaved under sterile conditions of $121^{\circ} \mathrm{C}, 2$ atmospheric pressures for 5 minutes for antigen retrieval. The sections were then immersed in $0.3 \% \mathrm{H}_{2} \mathrm{O}_{2} /$ methanol for 15 minutes to block endogenous peroxidase. A DAKO-LSAB2 Kit (for rat specimens; DAKO Co., Carpinteria, CA, USA) was used for immunohistochemical analysis. The primary antibody, monoclonal mouse, anti-human estrogen receptor (ER 1D5; DAKO) was diluted 50-fold and reacted overnight with the specimens at $4^{\circ} \mathrm{C}$ (Yuasa et al. 1996, 1997). Biotinylated secondary antibody was added for 10 minutes at room temperature, followed by peroxidase-labelled streptavidin under the same conditions. The chromogen 3,3'-diaminobenzidine (DAB) was reacted for 5 minutes at room temperature and the specimens were then counterstained with hematoxylin for 5 seconds.

Cytokeratin staining. A $3 \mu \mathrm{m}$ paraffin-embedded section was deparaffinized, 
and digested with protease type 27 (Sigma Chemical Co.) in $0.5 \mathrm{mg} / \mathrm{ml}$ of PBS for 30 minutes at $37^{\circ} \mathrm{C}$. Endogenous peroxidase was blocked using $0.3 \% \mathrm{H}_{2} \mathrm{O}_{2}$ / methanol for 15 minutes. Monoclonal mouse anti-human cytokeratin (high molecular weight) $34 \beta E 12$ (Enzo Diagnostics, Inc., Farmingdale, NY, USA) used as the primary antibody, was diluted 50-fold and reacted for 20 hours at room temperature, followed by $\mathrm{DAB}$ for 3 minutes. The remaining procedures were the same as those described for the $\operatorname{ER} \alpha$ staining.

$T G F \beta 1$ staining. Seminal vesicles were removed and immediately freezeembedded in OCT compound (TISSUE-TEK ${ }^{\circledR}$, Elkhart, IN, USA) under liquid nitrogen and stored at $-70^{\circ} \mathrm{C}$ until used. Frozen sections $(5 \mu \mathrm{m})$ were air-dried for 30 minutes and fixed in 10\% formalin/phosphate buffer, $\mathrm{pH} 7.4$ for 10 minutes at room temperature. Endogenous peroxidase was blocked by immersing the section in $0.3 \% \mathrm{H}_{2} \mathrm{O}_{2}$ /methanol for 15 minutes. Rabbit anti-TGF $\beta 1$ (V) (Santa Cruz Biotechnology Inc., Santa Cruz, CA, USA) used as the primary antibody, was diluted 100-fold and reacted for 24 hours at $4^{\circ} \mathrm{C}$, followed by DAKO EnVision plus $^{\mathrm{TM}}$, goat anti-rabbit immunoglobulin conjugated to peroxidase labelleddextran polymer for 60 minutes at room temperature. DAB was added for 5 minutes at room temperature. The remaining procedures were the same as those described for the $\mathrm{ER} \alpha$ staining.

\section{Results}

\section{Localization of nuclear ER $\alpha$ positive cells in glandular epithelium}

Many nuclear $\mathrm{ER} \alpha$ positive cells were located in the periglandular stroma region of the seminal vesicle 3 weeks after castration, but not in the glandular epithelium (Fig. 1a). However, when E2-silastic tubing was implanted subcutaneously into the back of an immature castrated rat, a few nuclear ER $\alpha$ positive cells appeared in the glandular epithelium within 24 hours (Fig. 1b). By the third day of estrogen administration, $19.29 \% \pm 3.39$ of the glandular epithelial cells were nuclear $\mathrm{ER} \alpha$ positive (Fig. 1c). At this point, the positive cells formed a single row in the basal portion of the glandular epithelium. By days 7 and 14, $43.19 \% \pm 6.27$ (Fig. 1d) and $74.05 \% \pm 5.14$ (Fig. le), respectively, of the glandular epithelial cells were $\mathrm{ER} \alpha$ positive. In particular, in areas with multilayer features, most cells were nuclear ER $\alpha$ positive (Fig. lf). Table 1 summarizes the effects of castration and estrogen administration on the localization of nuclear $\mathrm{ER} \alpha$ positive cells in glandular epithelium of seminal vesicles from immature castrated rats.

\section{Cytokeratin and TGF 1 staining of nuclear ER $\alpha$ positive epithelial cells}

Seminal vesicles with multilayer features were obtained from immature castrated rats that had received E2 for 14 days. Cells from these vesicles that were $\operatorname{ER} \alpha$ positive were also cytokeratin and $\operatorname{TGF} \beta 1$ positive (Figs. $2 \mathrm{a}$ and $\mathrm{b}$ ). Fig. 2c, $d$ and e show cytokeratin staining in the intact rat at 3 and 6 weeks of age 
and in the castrated rat at 6 weeks of age, respectively. Fig. $2 \mathrm{f}$, g and h show $\mathrm{TGF} \beta 1$ staining in the intact rat at 3 and 6 weeks of age and in the castrated rat at 6 weeks of age, respectively.

\section{Discussion}

The rat seminal vesicle consists of glandular epithelium and stroma. Stroma is comprised of periglandular and peripheral regions. We have shown that nuclear ER positive cells emerge in the seminal vesicles of immature castrated rats given estrogen (Yuasa et al. 1996). We also reported that nuclear ER positive cells in the seminal vesicle induced by estrogen were limited to the glandular epithelium and the peripheral stroma region (Yuasa et al. 1997). Furthermore, we reported that after the cessation of estrogen administration, the percentage of ER positive nuclei in the glandular epithelium and the peripheral stroma region significantly decreased. This indicated that estrogen upregulates ER expression in the glandular epithelium and in the peripheral stroma region. In the present study, we examined the fate of nuclear $\mathrm{ER} \alpha$ positive cells in the glandular epithelium after estrogen treatment, and investigated some of their characteristics by immunohistochemical means. In a previous study (Yuasa et al. 1993), we demonstrated that after 1-2 weeks of estrogen administration, some glandular epithelial cells of seminal vesicles of immature castrated rats showed multilayer features. In the above study, we showed that these cells with multilayer features were nuclear ER $\alpha$ and basal cell-specific cytokeratin (34 $\beta \mathrm{E} 12$ ) (Wojno and Epstein 1995) positive. These findings suggested characteristics of basal cells. These cells also expressed TGF $\beta 1$ as a result of estrogen administration. The proliferation of normal epithelial cells is usually inhibited by $\mathrm{TGF} \beta$, whereas that of stromal cells is stimulated (Moses et al. 1990). In addition, $\mathrm{TGF} \beta$ regulates cell motility, differentiation and adhesion and also promotes angiogenesis and extracellular matrix formation (Massague 1990; Nilsen 1990; Yang and Moses 1990). In the liver (Nakatsukasa et al. 1990) and kidney (Creely et al. 1992) $\mathrm{TGF} \beta$ also stimulates collagen synthesis. A recent study by our laboratory revealed that $\mathrm{TGF} \beta$ stimulates collagen synthesis by human prostatic stromal cells in vitro (Fukabori et al. 1997). Ashocroft et al. (1997) reported that aging in healthy females was associated with a reduced rate of cutaneous wound healing associated with decreased levels of $\mathrm{TGF} \beta 1$ immunostaining and steady-state mRNA in wounds. These age related changes were reversed by the systemic administration of estrogen. Moreover, ovariectomized young female rodents exhibited a marked delay in the repair of acute incisional wounds, which was reversed by the topical application of estrogen. An earlier report described that the Dunning R3327 PAP tumor contains high levels of TGF $\beta 1$, which are further increased by castration followed by estrogen administration (Lindstrom et al. 1996). However, since this increase is not apparent for 3 days, $\mathrm{TGF} \beta 1$ probably does not contribute to the induction of known apoptosis in the tumor 1 day after 
TABLE 1. Localization of nuclear ER $\alpha$ positive cells in glandular epithelium of seminal vesicles from immature castrated rats

\begin{tabular}{lcc}
\multicolumn{1}{c}{ Treatment } & $\begin{array}{c}\text { Age at } \\
\text { autopsy } \\
\text { (weeks) }\end{array}$ & $\begin{array}{c}\text { ER } \alpha \text {-cells } \\
\text { in glandular } \\
\text { epithelium (\%) }\end{array}$ \\
\hline Intact & 3 & $0(10)$ \\
Intact & 6 & $0(10)$ \\
Castrated, 3 week & 6 & $0(10)$ \\
Castrated, 3 week $+\mathrm{E} 2,1$ day & & $2.80 \pm 2.86(10)$ \\
Castrated, 3 week $+\mathrm{E} 2,3$ day & & $19.29 \pm 3.39(21)$ \\
Castrated, 3 week $+\mathrm{E} 2,7$ day & 7 & $43.19 \pm 6.27(21)$ \\
Castrated, 3 week $+\mathrm{E} 2$, 14 day & 8 & $74.05 \pm 5.14(21)$ \\
\hline
\end{tabular}

Values are expressed as mean \pm s.D., and values in parentheses indicate the number of individual observations. Percentages of nuclear ER $\alpha$ positive cells are evaluated in a blind fashion, using a light microscope, magnification $\times 1000$.

castration and estrogen administration. Our findings that TGF $\beta 1$ is expressed in the glandular epithelial cells of the seminal vesicle after castration combined with estrogen treatment reflect the results reported by Lindstrom et al. (1996) and suggest that $\mathrm{TGF} \beta$ expressed in glandular epithelial cells causes stromal cells to produce collagen.

\section{Acknowledgments}

This study was partly supported by a Grant-in-Aid for Scientific Research from the Ministry of Education, Science, Sports, and Culture of Japan.

\section{References}

1) Ashocroft, G.S., Dodsworth, J., Boxtel, E.V., Tarnuzzer, R.W., Horan, M.A., Schultz, G.S. \& Ferguson, M.W.J. (1997) Estrogen accelerates cutaneous wound healing associated with an increase in TGF- $\beta 1$ levels. Nat. Med., 3, 1209-1215.

2) Byers, M., Kuiper, G.G.J.M., Gustafsson, J.A. \& Park-Sarge, O.K. (1997) Estrogen receptor- $\beta$ mRNA expression in rat ovary: Down regulation by gonadotropins. Mol. Endocrinol., 11, 172-182.

3) Creely, J.J., DiMari, S.J., Howe, A.M. \& Haralson, M.A. (1992) Effects of transforming growth factor- $\beta$ on collagen synthesis by normal rat kidney epithelial cells. $A m$. J. Pathol., 140, 45-55.

4) Fukabori, Y., Nakano, K., Ohyama, A. \& Yamanaka, H. (1997) Stimulative Effect of transforming growth factor- $\beta$ on collagen synthesis by human prostatic stromal cells in vitro. Int. J. Urol., 4, 597-602.

5) Gustafsson, J.A. (1997) Estrogen receptor $\beta$ - Getting in on the action? Nat. Med., 3(5), 493-494.

6) Kuiper, G.G.J.M., Enmark, E., Pelto-Huikko, M., Nilsson, S. \& Gustafsson, J.A. (1996) Cloning of a novel estrogen receptor expressed in rat prostate and ovary. Proc. Natl. Acad. Sci. USA, 93, 5925-5930.

7) Lindstom, P., Bergh, A., Holm, I. \& Damber, J.E. (1996) Expression of Transforming growth factor- $\beta 1$ in rat ventral prostate and Dunning R3327 PAP prostate tumor 
after castration and estrogen treatment. Prostate, 29, 209-218.

8) Mariotti, A., Thornton, M. \& Mawhinney, M. (1981) Actions of androgen and estrogen on collagen levels in male accessory sex organs. Endocrinol., 109, 837-845.

9) Massague, J. (1990) The transforming growth factor- $\beta$ family. Ann. Rev. Cell Dev. Biol., 6, 597-641.

10) Moses, H.L., Yang, E.Y. \& Pietenpol, J.A. (1990) TGF- $\beta$ stimulation and inhibition of cell proliferation: New mechanistic insights. Cell, 63, 245-247.

11) Mosselman, S., Polman, J. \& Dijkema, R. (1996) ER $\beta$ : Identification and characterization of a novel human estrogen receptor. FEBS Lett., 392, 49-53.

12) Nakatsukasa, H., Nagy, P., Everts, R.P., Hsia, C.C., Marsden, E. \& Thorgeirsson, S.S. (1990) Cellular distribution of transforming growth factor-beta 1 and procollagen types I, and III transcripts in carbon tetrachloride-induced rat liver fibrosis. J. Clin. Invest., 85, 1833-1843.

13) Neubauer, B.L., Biser, P., Jones, C.D., Mariotti, A., Hoover, D.M., Thornton, T., Thornton, M.O. \& Goode, R.L. (1989) Antagonism of androgen and estrogen effects in gunea pig seminal vesicle epithelium and fibromuscular stroma by keoxifene. Prostate, 15, 273-286.

14) Nilsen, H.M. (1990) Transforming growth factor-beta and its actions on cellular growth and differentiation. Curr. Top. Dev. Biol., 24, 95-136

15) Ono, Y., Yuasa, H., Ohma, C., Mashimo, T., Suzuki, K. \& Yamanaka, H. (1995a) Eosinophils infiltration in the rat seminal vesicle associated with estrogen-17 $\beta$-related stromal proliferation. Tohoku J. Exp. Med., 175, 163-169.

16) Ono, Y., Yuasa, H., Ohma, C., Mashimo, T., Okabe, K., Kobayashi, D., Suzuki, K. \& Yamanaka, H. (1995b) Quantitative analysis of rat seminal vesicle stromal proliferation associated with E2-17 $\beta$ : Experience using an image analyzer SP500 sysrem (Olympus Co., Ltd.). Kitakanto Med. J., 45, 395-399.

17) Thornton, M.O., Frederickson, R., Mata, L. \& Mawhinney, M. (1984) Preliminary studies on the relationship between collagen and the growth of male accessory sex organ epithelial cells. In: New Approaches to Study of Benign Prostatic Hyperplasia, edited by F.A. Kimball, A.E. Buhl \& D.B. Canter, Alan R. Liss. Inc., New York, pp. 143-158.

18) vom Saal, F.S., Timms, B.G., Montano, M.M., Palanza, P., Thayer, K.A., Nagel, S.C., Dhar, M.D., Ganjam, V.K., Parmigiani, S. \& Welshons, W.V. (1997) Prostate enlargement in mice due to fetal exposure to low doses of estradiol or diethylstilbestrol and opposite effects at high doses. Proc. Natl. Acad. Sci. USA, 94, 2056-2061.

19) Wojno, K.J. \& Epstein, J.I. (1995) The utility of basal cell-specific anti-cytokeratin antibody $(34 \beta \mathrm{E} 12)$ in the diagnosis of prostate cancer. Am. J. Surg. Pathol., 19(3), 251-260.

20) Yang, E.Y. \& Moses, H.L. (1990) Transforming Growth Factor $\beta$ l-induced changes in cell migration,proliferation, and angiogenesis in the chickin chorioallantoic membrane. J. Cell Biol., 111, 731-741.

21) Yuasa, H., Fukabori, Y., Mashimo, T., Ohma, T., Suzuki, T., Yamanaka, H. \& Suzuki, K. (1993) The charasteristics of hormone responsiveness of glangular epithelium and stroma in male accessory sex organs. Acta Urol. Jpn., 39, 631-637.

22) Yuasa, H., Ono, Y., Ohma, T., Shimizu, N., Yamanaka, H., Uchida, T., Mizunuma, H., Aoki, K. \& Suzuki, K. (1996) The esrtogen-induced changes of estrogen receptor in seminal vesicle of immature castrated rat. Acta Urol. Jpn., 42, 33-37.

23) Yuasa, H., Ono, Y., Fukabori, Y., Ohma, T., Suzuki, K. \& Yamanaka, H. (1997) Effect of sex hormones on the tissue localization of nuclear receptor positively stained cells in the seminal vesicle of immature castrated rats. Tohoku J. Exp. Med., 181, 297-309.

24) Yuasa, H., Ono, Y., Fukabori, Y., Ohma, T., Yamanaka, H. \& Suzuki, K. (1998) Usefulness of the estrogen releasing silastic tubing. Kitakanto Med. J., 48, 15-18. 
Illustrations follow 
Fig. 1. Immunohistochemical findings of $\mathrm{ER} \alpha$ in glandular epithelium of seminal vesicles from immature castrated rats. Three weeks after castration, no nuclei were $\mathrm{ER} \alpha$ positive in glandular epithelium $(\mathrm{GE})(\mathrm{a})$. One day after estrogen administration, a few cells were nuclear $\mathrm{ER}_{\alpha}$ positive in $\mathrm{GE}$ (arrow)(b). Three days after estrogen administration, $19.29 \%$ of nuclei of cells in GE became $\mathrm{ER} \alpha$ positive, and formed a single row in the basal portion of $\mathrm{GE}$ (arrow)(c). Seven days after estrogen administration, the ratio of ER $\alpha$ positive cells increased to $43.19 \%$ (d) and after 14 days this increased to $74.05 \%$ (e). In areas with multilayer features, most cells were nuclear $\mathrm{ER} \alpha$ positive $(*)(f)$. GE, glandular epithelium; S, stroma. Original magnification $\times 400(\mathrm{a}-\mathrm{e}), \times 1000(\mathrm{f}) . \quad \mathrm{Bar}=25 \mu \mathrm{m}$. 

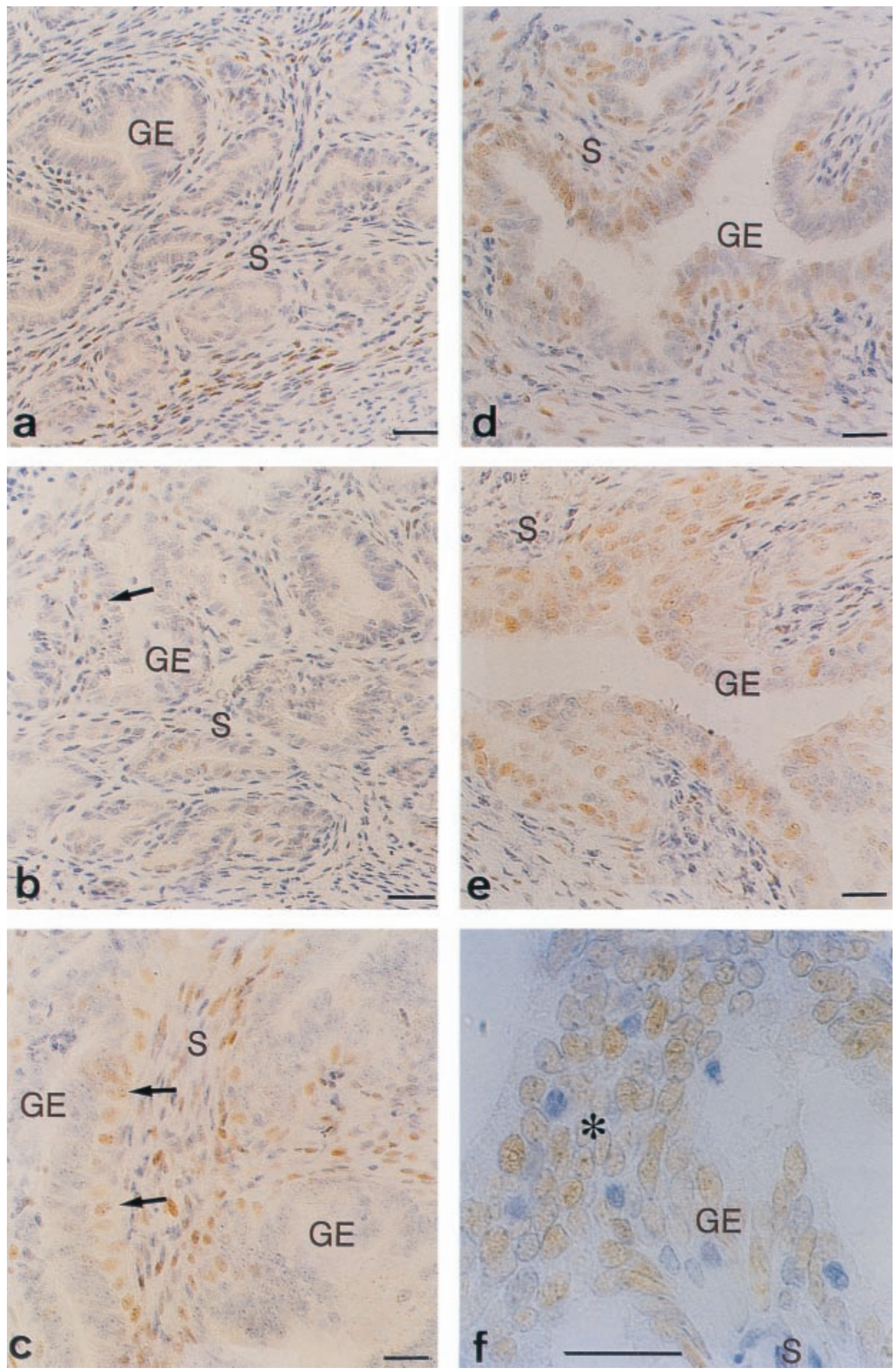
Fig. 2. Immunohistochemical findings of cytokeratin $(34 \beta \mathrm{E} 12)$ and $\mathrm{TGF} \beta 1$ in glandular epithelium of seminal vesicles from immature castrated rats.

Fourteen days after estrogen administration, cells that were positive for $\mathrm{ER} \alpha$, also stained for cytokeratin (a). TGF $\beta 1$ positivity at this time manifested as cytokeratin staining (b). Cytokeratin staining ( $c, d$ and $e)$. TGF $\beta 1$ staining $(f, g$ and $h)$. Intact, 3 weeks of age $(c, f)$. Intact, 6 weeks of age $(d, g)$. Three weeks after castration $(\mathrm{e}, \mathrm{h}) . \quad$ Original magnification $\times 400 . \quad$ Bar $=25$ $\mu \mathrm{m}$. 

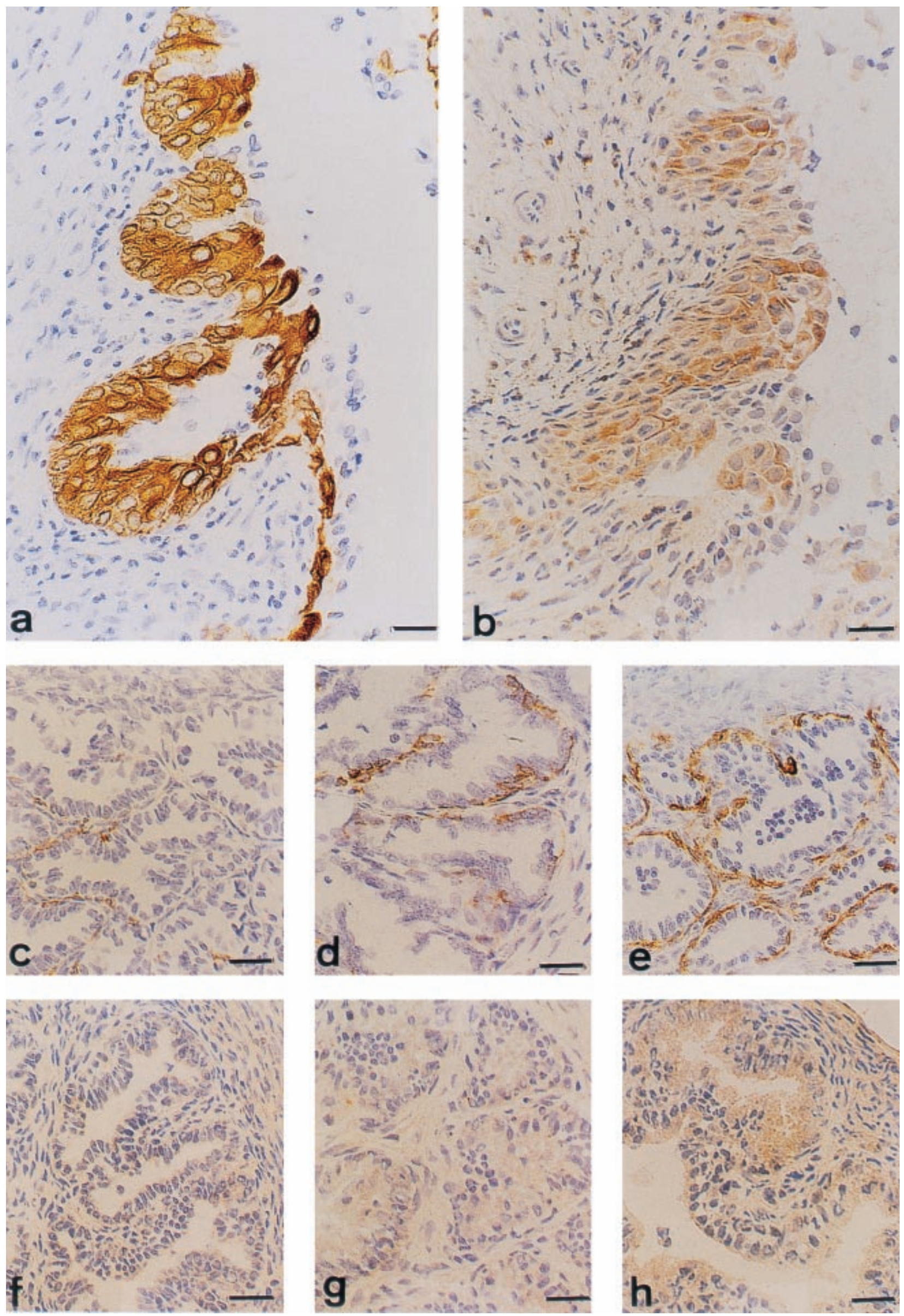